\title{
Research of operational features of heat accumulators using on motor transport
}

\author{
Kliuieva Oleksandra Olehivna, Rusanov Serhii Arkadiiovych \\ Kherson National Technical University, Kherson, Ukraine
}

\begin{abstract}
Preheating of the engine is often used to facilitate the start of the internal combustion engine in winter, which provides an opportunity not only to increase the comfort of starting, but also to reduce exhaust emissions, increase engine life. That is why the choice of optimal heat storage materials, which on the one hand would have sufficient heat efficiency and on the other hand would satisfy the operational requirements regarding corrosion activity, etc., is an urgent problem. In particular, the barium octohydrate used in our studies is corrosive, although it has a high heat of phase transition heat. The media investigated the media that are ordinary working fluids for heat transfer during heat accumulation: antifreeze, antifreeze, water; heat-accumulating materials - paraffins and octohydrates, and as investigated in relation to corrosion of material steel St 3 was considered. The working temperature range was used in the work. It was found that the corrosion rate of $3 \mathrm{~mm}$ per year in antifreeze and antifreeze environments requires the choice of anti-corrosion coating or the search for new material that will react.
\end{abstract}

Keywords: heat storage; corrosion; corrosion measurement

Not only the design and selection of optimal layouts of heat storage equipment used to facilitate the start of internal combustion engines (the main types of structures and types of heat storage processes are already widely developed), but also the choice of materials in terms of operational capabilities. In general, heat storage equipment for using to facilitate the start of car engines is designed with an emphasis on environmental issues, economy and even comfort of use - pre-commissioning of the car reduces exhaust emissions into the environment, increases the life of the car and facilitates the start of the engine in winter.

A significant experimental range of work on heat storage technology [1,2] identifies different classes of processes that can be used as targets for heat accumulation and reuse - in our case, the phase transition heat accumulators are considered as one of the most promising [3]. However, given the above, there is a question of taking into account the corrosive aggressiveness of materials, in particular (as an example) barium hydroxide octahydrate, which is one of the most common heat storage materials with high heat of phase transition and acceptable temperatures [4]. In addition, the corrosion resistance of the vapor "coolant - heat accumulator channels", given the importance of reducing the cost of equipment, but taking into account the interaction on service life, requires a detailed study of this issue (studied environments - antifreeze, antifreeze, water).

Currently, on the basis of the laboratory of Kherson National Technical University, we conduct a number of studies, in particular, the properties of heat storage materials. Samples of materials: copper, steel and aluminum in water, antifreeze and antifreeze were placed in the tank (Fig. 1).

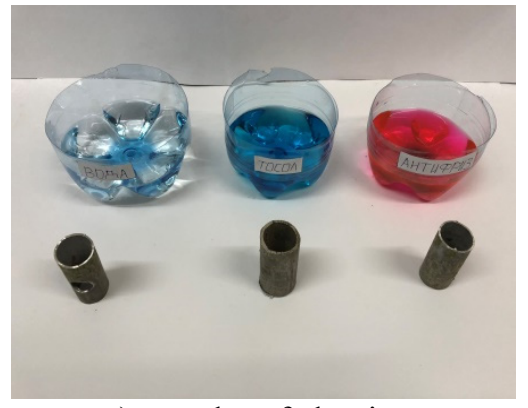

a) samples of aluminum

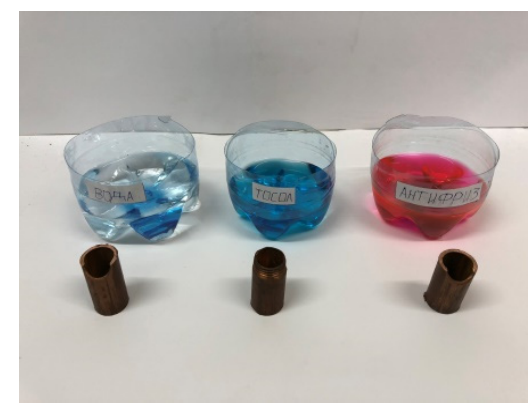

b) samples of copper

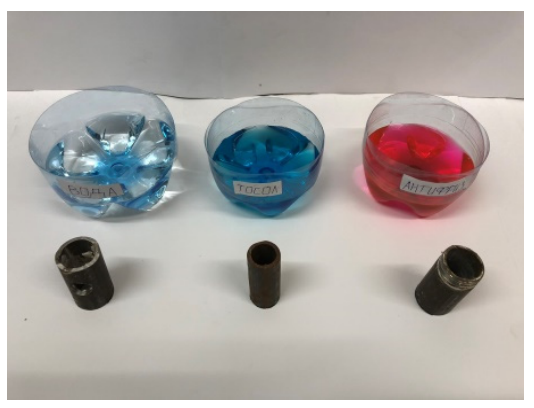

c) steel samples

Fig. 1. The process of immersion of samples 


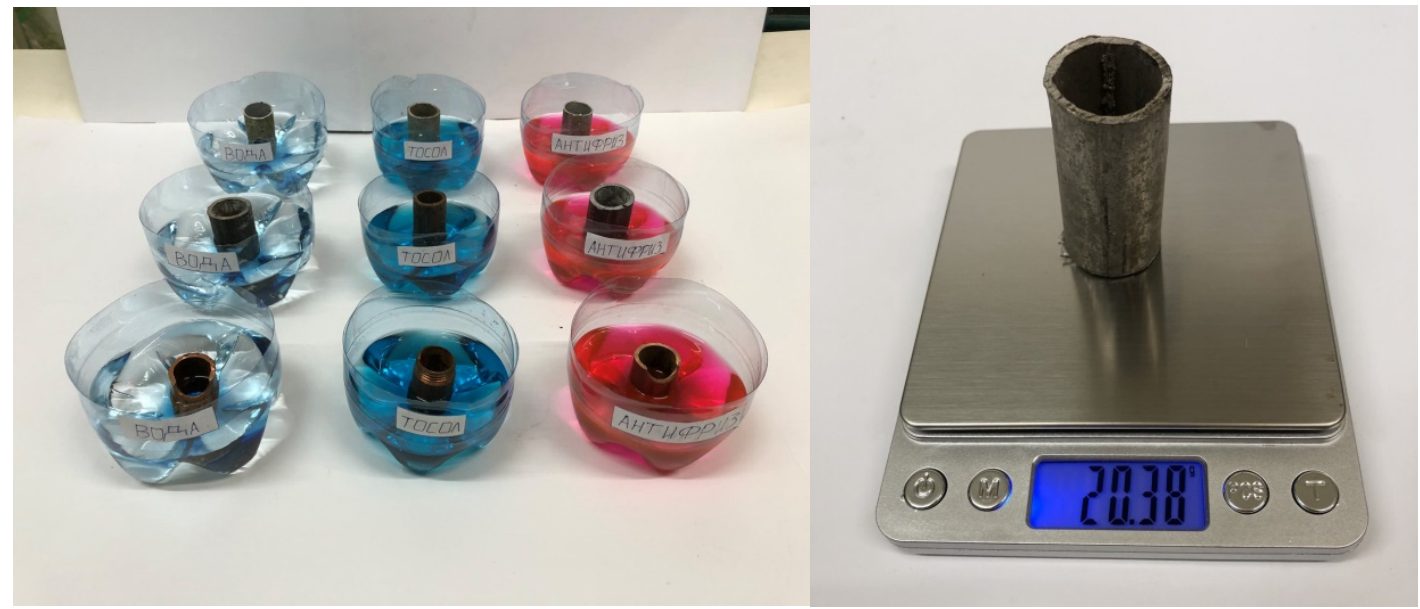

a)

b)

Fig. 2. $a$ - form of storage of experimental samples, $b$ - weighing of the sample

By the time of immersion of the samples, the weight of each of them was recorded using special scales with an accuracy of 0.01 grams (Fig. $2 b$ ). Determining the effect of the working fluid on the sample will be due to visual inspection and weight difference.

On the basis of the laboratory of Kherson National Technical University a number of studies are conducted on the corrosion meter P-5035, which controls the process of electrochemical corrosion, which occurs due to contact of the inhomogeneous surface of the electrode material with the electrolyte solution.

Studies of corrosion activity (corrosion rate) for contact of coolants (antifreeze and antifreeze), and as an anode - steel St 3 with temperature control (heating in the range from $30{ }^{\circ} \mathrm{C}$ to $90^{\circ} \mathrm{C}$, which corresponds to the operating temperature range for design according to [5]), after which the corrosion rate is determined on the device P-5035. The results of research show that the corrosion rate of steel St 3 about $3 \mathrm{~mm}$ per year on antifreeze and antifreeze at a temperature of $30{ }^{\circ} \mathrm{C}$ requires technological solutions in terms of reducing corrosion. These solutions can be implemented both in terms of the choice of materials (which can lead to increased design costs) and in terms of the use of anti-corrosion coatings.

\section{Список літератури}

1. Gil A., Medrano M., Martorell I., Lázaro A., Dolado P., Zalba B. State of the art on high temperature thermal energy storage for power generation. Part 1 - Concepts, materials and modellization, Renew Sustain Energy Rev, 14. 2010, pp. 31-55

2. Miró L., Gasia J., Cabeza L.F. Thermal energy storage (TES) for industrial waste heat (IWH) recovery: A review Apply Energy, 179, 2016, pp. 284-301

3. Sharmaa A., Tyagib V.V., Chena C.R., Buddhib D. Review on thermal energy storage with phase change materials and applications, 2009, pp. 318-345.

4. Kenisarin M.M., High-temperature phase change materials for thermal energy storage: Renew Sustain Energy Rev, 14. 2010, pp. 955-970.

5. Тепловий акумулятор системи передпускового прогріву двигуна внутрішнього згорання: пат. 137780 України, МПК F02N 17010 / Русанов С. А., Клюєв О. І., Аппазов Е. С., Луняка К. В., Коновалов Д. В., Мацків Б. М.; опубл. в бюл. № 21, 2019. 


\title{
Дослідження експлуатаційних особливостей використання теплових акумуляторів на автотранспорті
}

\section{Клюсва О.О., Русанов С.А.}

Херсонський національний технічний університет, Херсон, Україна

\begin{abstract}
Анотація. Для полегшення пуску двигуна внутрішнього згоряння в зимовий час часто використовується передпусковий підігрів двигуна, щуо надає можливість не тільки підвищити комфорт пуску, а й зменшити викиди відпрацьованих газів, підвищити ресурс двигуна. Саме тому актуальною проблемою є вибір оптимальних теплоакумуляиійних матеріалів, які б мали з одного боку достатню теплоефективність, а з іншого боку задовільнили б експлуатаційні вимоги, стосовно корозійної активності тощчо. Зокрема, октогідрат барію, щцо використовується в наших дослідженнях, є корозійно-агресивним, хоча і має високий показник теплоти фазового переходу. В роботі досліджувалися середовища, які є звичайними робочими рідинами для теплопереносу при акумулюванні теплоти: тосол, антифриз, вода; теплоакумуляиійні матеріали - парафіни та октогідрати, а в якості досліджуваного стосовно корозї матеріалу розглядалася сталь Ст3. В роботі використовувався робочий діапазон температур. Було виявлено, щзо швидкість корозії 3 мм за рік у середовищах тосолу та антифризу вимагає вибору антикорозійного покриття чи пошуку нового матеріалу, щзо буде вступати в реакиію.
\end{abstract}

Ключові слова: накопичення тепла; корозія; вимірювання корозії. 